\title{
Impact of Customer Satisfaction on Business: A Study on UK Telecommunication Industry
}

\author{
Sabrina Matin ${ }^{1}$, Ashiq Mahmud Bin Gholam Kibria ${ }^{2}$ \\ ${ }^{I}$ (Lecturer, School of Business, University of Information Technology and Sciences, Dhaka, Bangladesh) \\ ${ }^{2}$ (Lecturer, School of Business, University of Information Technology and Sciences, Dhaka, Bangladesh)
}

\begin{abstract}
The concept of Competitive advantage was first pronounced by a scholar Michael E. Porter in 1985. The basic idea of this theory advocates that every firm has its own distinctive feature, which helps it to stay in the competition. This distinctiveness is the competitive advantage for a firm. The firm needs to keep working on the existing competitive advantages and it should always keep looking for a new one that suits its needs. This article is an outcome of a research investigation of the competitive advantage of four leading mobile network providing companies in the United Kingdom, which includes Vodafone, T-Mobile, O2 and Orange; and the level of satisfaction for their customers. The core of this research has been the development of understanding of the competitive advantages of these four companies. There was a focus group interview conducted on the customers of the companies to understand the customer's satisfaction and their expectation from the mobile network providers. Data collected from the mobilephone users show that the competitive advantage for the companies is coming from different side of the business.An in-depth interview was also conducted on the managers of the mobile network providers to understand the competitive advantages of the companies and to learn what these companies are doing for their customers.
\end{abstract}

Keywords:- Competitive Advantage, Mobile Virtual Network Operator (MVNO), Tariff, $3 G$ (Third Generation), $4 G$ (Fourth Generation).

\section{Introduction}

Mobile phone is an important part of human life. This is the easier and quicker way people can contact each other. The UK mobile phone market recently experienced a dramatic growth. Till the mid of 80s, the mobile phone was only used by a few special groups like the security forces of UK. In 1998 over $15 \%$ of the population of the UK started subscribing mobile phone services and according to researchesthis subscription is growing at an amazing rate of $20 \%$ a year. As mobile phone makes use of a scarce resource, spectrum, this necessarily constrains the number of operating networks. For example, in the UK and in other European countries there are between two and four national digital GSM networks. Inevitably with such a small number of operators competition may not be effective. Nevertheless, the number of operators in most countries has increased in recent years and this has resulted in more competition.[1]

1.1. Network Operators

The current market structure in UK mobile telecommunications reflects past perceptions about likely developments in the mobile sector. There are the four network operators this research focused on:

1.1.1. $\mathrm{O} 2$

O2 was formed in 2001, following the demerger from British Telecom of its former mobile business, BT Wireless. $\mathrm{O} 2$ is a leading provider of mobile and broadband services to consumers and businesses in the UK. $\mathrm{O} 2 \mathrm{UK}$ is part of the Telefónica $\mathrm{O} 2$ Europe group which comprises integrated fixed/mobile businesses in the UK, Ireland, Germany, the Czech Republic and Slovakia. [2]

1.1.2. Vodafone Ltd

The UK's first mobile call was made from Vodafone at a few minutes past midnight on 1 January 1985. Within fifteen years of their operations, the company became the largest company in Europe and the largest of its kind anywhere in the world. [3]

1.1.3. T-Mobile

The origins of T-Mobile UK lie in Mercury Communications' mobile phone operation, Mercury One2One which was launched in 1993 as the world's first Digital Personal Communications Network. In August 1999 One2One was acquired by Deutshc Telekom and in April 2002 the company was re-branded as T-Mobile and in June 2002 they became the first UK operator to launch MMS picture messaging. T-Mobile is the UK's second largest operator (behind O2) with over 19 million subscribers. [4]

1.1.4. Orange 
Orange launched in April 1994 into the UK mobile communications market. The company was established with a vision of brighter communication future for the customers. Today Orange is one of the world's strongest and most recognised brands. [5]

Table-1.1 represents the market share of each network operator in the UK. It can be seen that the dominant operators in the UK market are $\mathrm{O} 2$ and Vodafone.

Table-1.1.: Mobile network operator's market share in UK

\begin{tabular}{|c|c|}
\hline Network & Market share \\
\hline O2 & $\mathbf{2 7 \%}$ \\
\hline Vodafone & $\mathbf{2 4 \%}$ \\
\hline T-Mobile & $\mathbf{2 1 \%}$ \\
\hline Orange & $\mathbf{2 0 \%}$ \\
\hline \multicolumn{2}{|c}{ Source: [6] } \\
\hline
\end{tabular}

\section{Literature Review}

Industry is the appropriate unit of analysis in setting competitive strategy. Strategically, industries are distinguishable by the products that they propose but the products might have similar sources of competitive advantage. In other words, the industry is the location where the firms win or lose a competitive advantage. To set a competitive advantage, the enterprise must define and elaborate a profitable approach of its industry.

\subsection{Origin of the Competitive Advantage}

The competitive advantage is used by the firms as a function to organise and manage their activities. There are various activities involved in an enterprise, which can be divided into: maintenance, conception, solicitation of the customers by the sellers and realisation of new products by the R\&D department. All these activities create value to the customers. The final value is created by the price the customers agree to pay for the product or the service their receiving from the firm. The firm is only profitable when this value is higher than the global cost. To get a competitive advantage against its competitors, the firm should supply its customers with the same value than the competitors and be more efficient in the production or elaborate specific activities that generate a greatest final value and authorise higher purchase prices (differentiation). When the enterprise conceives a new way to manage its activities and uses new technologies or different means of production, it may acquire a competitive advantage [7].

\subsection{ThePositioning in the Industry}

Considering the structure of the industry is not the only thing for an enterprise.It also has to decide an appropriate position for itself within the industry. The positioning of an enterprise has to match the options it had taken with regard to the market. The fundamental component of the positioning is the competitive advantage, which can be divided into advantage by low costs or advantage by differentiation. The advantage by low costs means that the company is more efficient than its competitors on the conception, the production, and the marketing of a product. The differentiation is the ability of the enterprise to supply its customers with a same product but of a better quality. In both cases, the competitive advantage translates into higher productivity of the enterprise [8]. In order to position itself within an industry the enterprise must determine the four dimension of the competitive scope:

i) Segment scope: the range of products it will propose;

ii) Vertical scope: the extent to which activities are performed in-house instead of by independent farms;

iii) Geographic scope: the type of customers it will attract, the range of regions and countries it will invest;

iv) Industry scope: the range of related industries in which the firm competes with a coordinated strategy [9]. 2.3. Sources of Competitive Advantage

A firm's competitive advantage can arise from one or more sources. Three sources are:

2.3.1. Ownership-based

2.3.2. Proficiency-based

2.3.3. Access-based

A firm can gain advantage by ownership or possession of certain valuable assets or factors, e.g. strong market position [10], unique resource endowment [11], or reputation [12]; by opportunity or rights to gain superior access to inputs and markets [13], e.g. exclusive relationship with supplier or distribution channel; by superior knowledge, competence, or capabilities in conducting and managing its business processes [14][15][16] producing quality products at lower costs and delivering the right products and/or service to its customers in the right place at the right price and time through the right channels [17]. Achieving any advantage in business needs an intense and systematic analysis into what the firm has, what it knows, and what it can get. The advantage that comes from any of these sources (ownership, access, or knowledge based) allows one firm to provide better customer value than others. Any factor that contributes to the existence or enlargement a 
differential could serve as a source of firm advantage (see Figure 1). That is, to gain advantage, a firm could focus on raising the playing level of it; it could also proactively constrain or belittle rivals [18].

\section{Figure 1}

Generic sources of competitive advantage

\begin{tabular}{|c|c|c|}
\hline & Creation-Oriented & Preemption-Oriented \\
\hline Ownership-Based & $\begin{array}{l}\text { Actively Acquire } \\
\text { Valuable Assets }\end{array}$ & $\begin{array}{l}\text { Constrain Rivals' } \\
\text { Options in Acquiring } \\
\text { Valuable Assets }\end{array}$ \\
\hline Access-Based & $\begin{array}{l}\text { Build Gateway } \\
\text { for Access }\end{array}$ & $\begin{array}{l}\text { Deny or Limit } \\
\text { Rivals' Access }\end{array}$ \\
\hline Proficiency-Based & $\begin{array}{l}\text { Foster } \\
\text { Organizational } \\
\text { Learning and } \\
\text { Refine Routine }\end{array}$ & $\begin{array}{l}\text { Discourage } \\
\text { Rivals' } \\
\text { Learning and } \\
\text { Imitating }\end{array}$ \\
\hline
\end{tabular}

\subsection{The Context for Competitive Advantage}

\section{Source: [19]}

The long term challenge for any firm is to put itself in a position where it is most likely to perceive and able to address the imperatives of competitive advantage. The challenge is not an easy one, because the bias toward continuing past modes of behaviour is strong. One problem is to expose a company to new market and technological opportunities that may be hard to perceive. Another is preparing for change by upgrading and expanding the skills of employees and improving the firm's scientific and knowledge base. Ultimately, the most important challenge is overcoming complacency and inertia to act on the new opportunities and circumstances[20].

\subsection{Customer Satisfaction}

Customer satisfaction is defined as a customer's overall evaluation of the performance of an offering to date [21]. This overall satisfaction has a strong positive effect on customer loyalty, intentions across a wide range of product and service categories, including telecommunications services [22][23]. As an overall evaluation that is built up over time, satisfaction typically mediates the effects of product quality, service quality, and price or payment equity on loyalty [24][25]. It also contains a significant affective component, which is created through repeated product or service usage [26]In a service context, overall satisfaction is similar to overall evaluations of service quality. Bolton [27] finds a positive effect of overall customer satisfaction on the duration of the relationship for cellular phone customers, and Bolton and Lemon [28] show a positive effect of overall satisfaction on customer usage of telecommunications subscription services [29].

2.6. Outcomes of Customer Satisfaction

The outcome of customer satisfaction can be distinguished in four categories:

a. Customer-related

b. Employee-related

c. Efficiency-related

d. Overall performance-related outcomes

The last category is related to general performance outcomes, which are bottom line in nature. Studies that fall into this category examine financial performance outcomes of customer satisfaction. There is enough evidence in the marketing literature that customer satisfaction acts an important driver of a firm's profitability. For example, researches show that the customer satisfaction has a positive impact on financial performance measures of a firm, such as return on investment and return on assets. The other three categories of satisfaction outcomes provide more specific explanations for the positive impact of customer satisfaction on firm profitability. 


\subsection{Customer Satisfaction and Profitability}

There are two different conceptualizations of customer satisfaction:

- Transaction-specific

- Cumulative

From a transaction-specific perspective, customer satisfaction is viewed as a post-choice evaluative judgment of a specific purchase occasion [30][31]. Behavioural researchers in marketing have developed a rich body of literature investigating the antecedents and consequences of this type of customer satisfaction at the individual level (see Yi 1991 for a review). By comparison, cumulative customer satisfaction is an overall evaluation based on the total purchase and consumption experience with a good or service over time [32][33]. Whereas transaction- specific satisfaction may provide specific diagnostic information about a particular product or service encounter, cumulative satisfaction is a more fundamental indicator of the firm's past, current, and future performance.

\section{Research Objectives}

The overall objective is 'to examine the competitive advantage of the mobile network providers and the impact of customer satisfaction on the competitive advantage'. This has been broken into the following sub-objectives:

- To find out competitive advantage of different mobile network providers

- To find out customers expectation from their network providers

- To examine if the customers satisfaction is adding any competitive advantages to the mobile network companies.

\subsection{Data Sources}

\section{Research Plan}

The research is based on both primary and secondary data collected from mobile phone users and the managers of different mobile network providers in city of Chelmsford,the United Kingdom (UK).

4.2. Research Approaches

This research used both qualitative research and desk research approaches. The desk research phase will gather information on competitive advantage itself and the customers' expectations. This will give a useful indication about the status of the marketplace as well. The qualitative research was used to explore and understand the attitudes of customers towards the mobile network providing companies and their opinions about the products and services they are getting from these companies. The qualitative research was also used to find out the services that the mobile network providers are offering to their customers.

4.3. Research Instrument

The research used a 45 minutesin-depth interview session to interview the customers. To assure the effectiveness of the discussion, particular questions about all four mobile network providers have been asked to all the members of the group. 4 managers from 4 mobile networks providing companies were interviewed. Each interview lasted for 15 minutes. To assure the effectiveness of the interview, particular questions about the product and services of the mobile network providing companies have been asked.

\subsection{Sampling Plan}

4.4.1. SampleUnit

Customers of four different mobile network providing companies were chosen as the sample unit. The age limit for the sample unit was 20 to 64 .

4.4.2. Sample Size: The research considered a sample of 12participants from the customers of different mobile network providers for the focus group interview and 4 managers from four different mobile network providers for the manager's interview.

\subsection{Key Findings}

\section{Result}

The following research helps to disclose the competitive advantages of the mobile network providing companies and the customer satisfaction and its impact on the competitive advantage. The researcher interviewed the managers of different mobile network providers and a focus group interview consisting mobile phone customers took place as well.

The key findings from the research are:

- According to Mintel report over $90 \%$ of UK population use mobile phone.

- Customers like to have good services from their mobile network providers, but most of the customers like to have a lower price option.

- $\mathrm{O} 2$ is the most expensive mobile network provider in the market but surprisingly they are the market leader too. 
- Customers are more interested in smart phones now and to make the most a smart phone they are now preferring to have unlimited data allowance included in the tariff plan.

- The mobile network providing companies are working on satisfying the customers and for this different companies are following different strategies. Some companies are going for professionalism, some are going for the friendly customer services and others are choosing a low price strategy to satisfy the customers.

- People tend to go for a good tariff consisting handsome allowance of airtime, data and text messaging and they want it all for a moderate price.

- Although, most of the customers are already quite happy with the services of their network providers, they are still looking for some new services.

\section{DESK RESEARCH}

The desk research covered the following topics:

- What percentage of UK population uses mobile phone?

- What kinds of services do they use?

- What prices are charged?

- Who is the current market leader now?

- What promotions are currently used?

- Who are the target audience?

The mobile network providing companies experienced a decline during the recession in the year 20082009. Now it is getting its growth back since 2010, with the market estimated to reach 84.27 million subscribers by 2012 [34].

According to Mobile Market Research[35]report, about 30\%-35\% UK mobile customers are happy to go for a second contract with the same company after finishing the first one. And around $25 \%$ of the customers are keen to try a different mobile network provider after finishing the existing contract. People normally use tariffs which include more airtime and a moderate allowance of text messages. But the teenage customers are mostly interested in getting more text messages in their tariff. Customers who are using a smart phone or phones with an online browser use tariff with data allowance. Prices for the different tariffs vary depending on the network provider. A tariff with moderated amount of airtime, text messages and data allowance costs $£ 30-£ 45$ depending on the handset. Different network providers are charging different prices for almost similar tariff. Among all the providers, $\mathrm{O} 2$ is the most expensive one but the company is still holding the leading position in the market. People are looking at buying contract that can be beneficial for the whole family. A T-Mobile contract where customers can get unlimited anytime calls to other T-Mobile numbers or the Orange family offer from Orange, which includes unlimited anytime calls to any UK landline. Research shows that there are people who want go for the phone they like and not very concerned about the tariff.

\section{Qualitative Research Analysis}

The Qualitative research had two sections; the first section involves running a focus group interview with the customers of mobile network providers. The second section involves interviewing the managers of different mobile network providers. Here the researcher has taken four mobile network providing companies serving the United Kingdom customers. The companies are: Vodafone, T-Mobile, $\mathrm{O} 2$ and Orange.

This is an attempt to analyse the feedback from both the customers of mobile network providers and the managers of the mobile network providers.

\subsection{QualitativeResearch Analysis for Customers}

\subsubsection{FocusGroup Findings}

According to the focus group questionnaire, the researcher identified 7 key points for the qualitative research findings. They include:

\subsubsection{Customer'sLikings about Their Network Provider}

All customers like the service quality of their network providers. Vodafone's customer like the strong network signal that Vodafone provides for the customers. Although no other participants of the focus group experienced a signal interruption with their network providers. T-Mobile customers like the simplicity of their customer service. According to the customers, it is very simple to get help from the customer service of TMobile. Customers also like the intra-network facilities that T-Mobile offers and which other companies do not have. Customers of $\mathrm{O} 2$ like the professionalism about the company.O2 offers a high standard customer service for the customers. With Orange, customers like the cheap tariff plan that the company offers. Though Orange does not follow a low price strategy, it offers cheap mobile deals for its customers. Right after the launching of iPhone $4 \mathrm{~s}$, orange introduced a contract of this phone for only $£ 31$ a month. This tariff was almost $20 \%$ cheaper than those of the other companies in the market. 


\subsubsection{Customer'sThoughts about the Services of Their Network Provider}

Customer's thought about their network providers are quite similar. All the members of the focus group think they are getting more or less similar services from their network providers. Vodafone's customers think that Vodafone has a very friendly customer service. They have got nice and friendly people who are always ready to help the customers. However some customers of Vodafone disagree with this comment. According to these dis-satisfied customers, Vodafone is lacking a well-structured communication among the different departments of the company. Moreover Vodafone has its call centre outside UK which,some customers think another negative side of the company. T-Mobile offers free calls to other T-Mobile numbers. Customers think this is a great way to be connected to their friends and family. 2 of the focus group participants who are TMobile customers got other family members using T-Mobile as well. They are enjoying the free T-Mobile to TMobile calls and they do not have to worry about going over their limit. And customers also get a bonus from TMobile when they introduce their friends. Among all the companies, $\mathrm{O} 2$ maintains a high standard of performance but their chargesare very high.O2 has got UK based call centre which some customers really like about $\mathrm{O} 2$ because they can get the information just by calling the call centre and they do not have to go to an $\mathrm{O} 2$ shop. $\mathrm{O} 2$ gives $10 \%$ bonus on every top up to their pay as you go numbers. Orange customers like the innovative side of orange. For example, almost all the customers like the small sized tariff plan of Orange where customers get a minimum allowance of airtime, text messaging and data but they can get a smart phone or an android phone for a relatively low priced monthly contract and the phone is for free. Moreover, customers get free unlimited anytime calls to UK landlines with some of the Orange contracts.

\subsubsection{Customer'sLikings about the Services of Their Network Provider}

All participants of the focus groupthink that there are so many amazing things that their network providers are doing for them. Everyone has their favourite side of the services they are getting from their mobile network providers. The customers of Vodafone like the friendly approach of the company's people. Customers like the good strength of the signal and clear sound quality of Vodafone. Vodafone does not offer the lowest price in the market but it is still cheaper than $\mathrm{O} 2$. And Vodafone offers students discount and multi contract discounts for its customers. The customers like the fact that they are getting a good tariff plan at a comparatively low price along with a friendly customer service. The customers of T-Mobile think that, the free unlimited calls to other T-Mobile numbers are the best thing that the company is doing for its customers. The customer also like that T-Mobile is offering the cheapest international calls in the market. One of the focus group participants mentioned that his family lives in Bangladesh, and calling his country from his T-Mobile number is not any expensive than calling with a calling card or from other phone services. Customers of $\mathrm{O} 2$ like the professionalism and the high quality of the services. Though they get charged a little higher than the customers of other companies, $\mathrm{O} 2$ customers still think to some extent it is worth paying extra. Customers of $\mathrm{O} 2$ like another thing of $\mathrm{O} 2$ which is deal of the month or deal of the week. These are basically promotional offers that $\mathrm{O} 2$ launches for its customers (both existing and new). Under an offer like this the customer can get up to 50\% off on an existing deal or the company sometimes launches an entirely new tariff for that promotional offer. The customers of Orange get charged per second. Even when a customer is using his contract's minutes the company charge him exactly the same way. This means if a customer is finishing a call at 1 minute and 40 seconds, Orange will cut exactly 1 minute and 40 seconds from his contract minutes and the customer will leave with rest of his contract minutes and 20 seconds. This is something that customers really appreciate. They like the idea that they are getting charged for exactly what they are consuming.

\subsubsection{Customer'sThoughts about the Pricing of Their Network Provider}

Apart from T-Mobile customers, everyone else think that they are paying high price for their contract with the mobile network providers. Although all the participants of the focus group think that $\mathrm{O} 2$ is the most expensive mobile network provider, no one could give up the idea of being stuck with a high priced contract with their mobile network provider. Even the customers of T-Mobile think that the price they are paying is quite similar to those of other networks, because to get the services like unlimited calls to any T-Mobile numbers and the low priced international call the customers have to pay a minimum of $£ 30$ a month. Moreover, calling a MVNO (Mobile Virtual Network Operator) number from a T-Mobile number costs the customers between 1425 pence whereas, the other mobile network providers do not charge for calling these numbers. The customers of Vodafone agree that the company is not charging the highest price in the market, but they are still charging higher than those of some of the other companies. Vodafone offers student discount and multi contract discount for their customers, but the discounted prices are still not very low-priced option. The customers of $\mathrm{O} 2$ along with the other participants of the focus group have a strong believe that, $\mathrm{O} 2$ is the most expensive mobile network provider in the country. Although customers are happy about the services they are getting from $\mathrm{O} 2$, they still think $\mathrm{O} 2$ needs to work on its pricing strategy and come up with some lower price options for their customers. With the small sized tariff plan and the per-second charge, Orange seems to be the most attractive 
mobile network provider among the four companies. The only objection of the customers is they do not get a good tariff plan if they are choosing a smart phone or an android phone.

\subsubsection{Customer'sExpectations about Their Network Provider}

The customers of all the mobile network providers are quite happy about the services they are getting from their network provider. But almost all of them want something more from their network providers. The customers of Vodafone want the company to cut down the price a little bit and increase the limit of data allowance. According to one of the participant of the focus group and an existing customer of Vodafone, 750Mb or $1 \mathrm{~Gb}$ data allowance is not always enough. So the customers expect Vodafone to provide unlimited data allowance for a lower price plan. T-Mobile customers are happy about the services they are getting and the price they are paying for it. But they want T-Mobile to reduce the calling charge to any MVNO numbers. The customers of $\mathrm{O} 2$ expect the company to reduce the price for the services it provides. Despite the high standard of services the customers of $\mathrm{O} 2$ are not very satisfied customers as they arepaying a high price for the services. Orange's customers like the small sized tariff plan and the per-second charging strategy of the company. But some of the customers, who prefer a smart phone; think that orange should come up with a new pricing strategy where the customer will be able to get a contract of a smart phone along with a handsome tariff plan and a moderated price of the contract.

\subsubsection{TheServices Customers Think Their Network Provider Should Have}

Customers are getting a lot of different services from their service providers. But many of them still want their network providers to add other useful services to their services. A common interest is about the $4 \mathrm{G}$ (Fourth Generation) technology. All the participants of the focus group want their network providers to introduce the $4 \mathrm{G}$ technology. The reasons that customers asking for this technology to be introduced is, it enables the super-fast internet access. With the help of the $4 \mathrm{G}$ technology, the customer will enjoy a super-fast internet experience and they will be able to upload or download files, photos, documents in the fastest ever speed whenever and where ever they want.

\subsubsection{ThingsCustomers Dislike abouttheir Network Provider}

Discussing this issue, the customers expressed different type of the dissatisfaction about their network providers. There were billing issues, miscommunication issues, surprise charges and many others. The customers of Vodafone raised a very serious issue of over billing and mysterious charges that they experienced with the company. One of the focus group participants said he paid Vodafone almost five times more than his contract price for over a year. At the first point right after receiving the first huge amount bill when he contacted the Vodafone call centre; they told him that he went over his limit.The customer received the huge amount of bill each month for 14 months. Then at the end of his contract period when he went to the Vodafone store, one of their sales advisers told him that,he did not have the tariff plan in his contract that he actually asked for. And this was the reason for him to get overcharged for 14 month. After an investigation done by the network provider, it has been found that the person who gave him the contract made this mistake. He put through a different tariff plan than the one the customer agreed for. One of the $\mathrm{O} 2$ customers said he got charged for the hand set he had taken. But when he took the contract, he had been told that the hand set was free. The participants of the focus group from the other two network providers have not had any unpleasant experience with their network providers. But all participants agreed that miscommunication happens when both the customer and the sales person do not pay enough attention to the details.

\subsection{QualitativeResearch Analysis for Managers:}

\subsubsection{TheFindings of the Interview}

According to the questionnaire for the managers, the researcher identified 5 key points for the qualitative research findings. They include:

\subsubsection{TheWays to Keep the Customers Happy}

All the mobile network providers try to keep their customers happy as much as they can. But different companies follow different strategy to do that. Vodafone offers their customers a friendly customer service. They prefer having real engagement with the customers. T-Mobile wants to provide a simple customer service to the customers. They believe in providing customised services to the customers as well. O2 believes in professionalism. They maintain a high quality of their services. Orange offers customer friendly services as well. They want to make their customers feel welcome and comfortable.

\subsubsection{TheWays toDifferentiate the Services from Others}

When it comes to differentiating the services from others, Vodafone believes in delivering one2one relationship to the customers. They like to serve their customers on one2one basis; this involves more engagement, personal touch with the customers. Apart from that Vodafone claims to have the strongest network 
coverage in the country. They believe this strongest network coverage is well enough to differentiate their services from others. T-Mobile offers the highest possible value for money. They offer their customers many intra network facilities which the customers cannot get anywhere else. T-Mobile believes these differentiate their services from others. O2 again believes their professionalism and high standard of services are so remarkable and this is the means to differentiate their services from others. Orange offers the small size tariff plans and the per-second charges, which are incredible offers for the customers. They think, their customers appreciate these services and this helps them stand one step ahead of the others.

\subsubsection{TheStrategy to Retain Customers}

To retain their existing customers all the companies have their own strategies and plans. Vodafone offers discounts, special price plans, and customised tariff to retain their customers. They also offer free tickets for music shows, cinemas and fashion shows to their customers. T-Mobile offers customised tariff to retain their customers as well. They also offer customised solutions to their customers.For example, if a customer needs more minutes or data allowances, T-Mobile tries to meet their needs within the same price plans. To retain their customers, $\mathrm{O} 2$ offers a price match for their customers. For example, at the end of the contract, if a customer wants to update the contract and challenge the price plan of $\mathrm{O} 2$ with other network providers, $\mathrm{O} 2$ will try to give the customer the challenged tariff. Orange brings new cheaper price plan for the customers who are about to finish their contract. They sometimes cut down the price of the contract if the customer is happy to carry on with the same tariff.

\subsubsection{TheCompetitive Advantages}

According to Vodafone, their network reliability is the strongest competitive advantage for them. They have strong network coverage. Their customers never experienced a single occasion of signal droop or poor connection quality. According toT-Mobile, the competitive advantage for them is the international packages they offer to the customers. With their international package, the customers can make free overseas call and within their regular packages the customer can also make cheap overseas call for as little as less than 5p a minute. $\mathrm{O} 2$ thinks their competitive advantage is the high quality of their services. They are the most expensive in the market. But still they have got the highest market share. This proves the service quality is adding competitive advantages to the company. Orange provides small size price plan where customers can get an expensive phone for free with the contract at a moderate price. This adds the competitive advantages to the brand.

\subsubsection{TheWays toOffer Better Customer Services than the Other Companies}

Engaging with the customers and providing an One2One relationship is the prime way to offer better customer service to the customers for Vodafone. Vodafone believes, the special offers, discounted price and customised service are some of the main elements for them to offer better customer services. This helps them to keep their customers happy and retain them for a longer period of time. Providing a good value for the money is the way T-Mobile provides better customer service to their customers. At T-Mobile, customers can get lots of extra services for a relatively similar price. The price match of $\mathrm{O} 2$ provides better customer service for the customers. Apart from these, $\mathrm{O} 2$ offers discounted home broad band and multi connection discounts to their customers. $\mathrm{O} 2$ has recently introduced a service called $\mathrm{O} 2$ money, where customers can top up a card provided by $\mathrm{O} 2$ and use it like a debit or credit card. Orange offers many customised services for their customers as per the age, need and income of the customers.

\section{Analysis}

Analysing these key point we can see, customers of different network providers like different things about their network providing companies. Some customers like the good service quality, some like the low price strategy and some like the high standard maintained by the company. Though different mobile network providing companies are holding different positions in the market, every company has its own competitive advantage. All these four companies are offering almost similar services but they are charging different prices. According to Passemard and Brian (2000), the competitive advantage has two different components:i) advantage by low cost and ii) advantage by differentiation. Here in this case, T-Mobile is positioning itself with the competitive advantage of low costs. This company is offering low priced tariff plans compared to its competitors. They are also offering many intra network facilities and low cost international calls for the customers. The low cost strategy is attracting customers to the company. And here the company is getting competitive advantage over some of its competitors. The company is holding the third position among UK's mobile network providing companies. On the contrary, $\mathrm{O} 2$ is positioning the company in the market on the basis of differentiation. They are differentiating themselves from competitors with their high standard of service quality. $\mathrm{O} 2$ maintains a very high standard of service quality. They are offering more or less same tariff to the 
customer but the quality of their services is very high. This high quality of services is giving the company very strong competitive advantage over their competitors. Though the customers of the company think $\mathrm{O} 2$ is providing their services to the customers in a little complicated way than its competitors, they are still happy with the company's performance. And for this reason $\mathrm{O} 2$ is holding the leading position in the market. But offering a high standard performance and high quality services is costly[26]. This is why $\mathrm{O} 2$ is the most expensive network provider in the market too. But the high price of their services is not obstructing the company from attracting a large number of customers in the market. The other two companies, Vodafone and Orange are not positioning themselves on any of these two components of competitive advantage in the market. Though these two companies are offering good services and low priced tariff plan to the customers, none of the companies are following low price strategy or a differentiation strategy. Vodafone offers tariff plans for a moderated price and they have a friendly customer service. But they have their call centre outside UK which is holding the company back in the competition. According to Porter [37], "firms should locate all its activities within the nation it serving. This helps the firms to achieve stronger competitive advantage over their competitors." Vodafone offers multi contract discounts and students' discounts for their customers, which is a positive side of the company. Vodafone is also providing the strongest network signal among all the four companies. Though there is no complain of a weaker signal from the customers of other network providers, this feature is giving Vodafone a bit of competitive advantage. Porter [38] suggests that companies can obtain differentiation and reduce its costs by applying improved technology. This gives the companies a chance to retain customers and stay ahead in the competition. In the case of Vodafone, providing strongest network or using $4 \mathrm{G}$ technology for their network services is giving the company a competitive advantage over its competitors. And because of the advanced technology Vodafone is getting a good number of customers and leading the market as the second largest mobile network providing company. But in long run, when improved technology will become available to everyone, the company will have to choose one of the competitive advantage components: either low cost or differentiation. Orange offers small sized price plan for its customers which is clearly not a low price strategy. Orange is not following a differentiation strategy as well. Though the company is offering a number of good tariff plans, they are not following any specific strategy. According to Passemard and Brian, "The worst strategy for the firm is not to choose a particular strategy: This will drive the company to a bad strategy position that will bring low profitability."[39] As Orange is not following any particular strategy the company might face a bad strategy position and low profitability in future.

\section{Conclusion}

The competitive advantage is undoubtedly an important element of the business. It takes a lot hard work to create a competitive advantage. The companies need to progress, to innovate, and to discover the best competitive opportunities and use them. It does not matter how successful a company is.They should not stop improving the quality of their products. According to Stewart [40], "A firm that constantly learns accumulates and expands its knowledge base or intellectual capital enjoys competitive advantage." It was found in this research that $\mathrm{O} 2$ is the market leader among all the mobile network providing companies. But $\mathrm{O} 2$ is the most expensive company in the market too. The reason for this high expense is the differentiation strategy the company is applying. Andthe differentiation strategy is the reason that $\mathrm{O} 2$ is getting the hold on the market. Customers of $\mathrm{O} 2$ like the high quality of its services. But the customers have complaints against the complicated customer services and the high price strategy of the company.The customers like UK based call center of the company, because a UK based call center helps reduce the miscommunications between departments. Vodafone has the second largest share of the market among the mobile network providers in the country. According to Fornell et al. [41], "The overall satisfaction has a strong positive effect on customer loyalty intentions across a wide range of product and service categories, including telecommunications services." Customers of Vodafone like the friendly customer service of the company and reliability of the network. This is where the company is getting competitive advantage. But according to the company people,the strong network coverage is the competitive advantage for them. This can be true as well. Because strong network coverage means Vodafone is helping its customers to be connected in a better way. As a result, Vodafone is enjoying customer satisfaction. Though Vodafone is not charging as high as $\mathrm{O} 2$ for its services, it is still one of the expensive companies in the market. Vodafone has some highly dissatisfied customers too: customers who do not like the idea of having the call centre outside UK and customers who experienced problems because of the miscommunication between different departments of Vodafone. T-Mobile is the third largest mobile network providing company among these four. It has a strong competitive advantage that is the low cost strategy of the business. This means customers of T-Mobile can enjoy the same services like the customers of other three companies, but in a relatively low price. Besides, T-Mobile offers many intra network facilities for its customers. Free unlimited any time calls to other T-Mobile numbers is one of them. T-Mobile also offers the customers low priced international calls and sometimes the international calls are free to make under some tariff plans. These features give the company a great privilege over others. The only thing that makes customers unhappy about the T- 
Mobile is that they charge their customers to call the MVNO numbers. Orange has the lowest size of the market share among these four companies. The competitive advantage of Orange probably is the per-second charge and small size tariff plan they offer their customers. With the per second charge plan, all customers of Orange get charged for the seconds they use. With the small sized tariff plan, customers can get an expensive phone for a very low monthly payment. Orange provides friendly customer service for its customers. But the customers of Orange still have some complaints about the company. For example, with the small size tariff plan customer can only get a good hand set, but the tariff is not a very standard one. Besides everything, Orange does not seem to be following any specific strategy for its business. The company is not applying a specific strategy to run the business. But this is not worthy for the business because following no strategy might put the company in a difficult situation. According to scholars, if a firm is not choosing any particular strategy; this is the worst strategy that firm is going for. And this will drive the firm to a bad strategy position which will bring low profitability for the business.

\subsection{Recommendation for $\mathrm{O2}$}

\section{Recommendation}

$\mathrm{O} 2$ is the most expensive mobile network provider in the market and some of their customers do not like the high tariff price strategy of the company. So O2 should work on its pricing strategy and cut it down. Some of O2'scustomers felt that the company has a very complicated and time consuming customer service. This is creating some highly dissatisfied customers. To avoid unpopularity, $\mathrm{O} 2$ should try to improve this issue. Though $\mathrm{O} 2$ is the market leader, it should still come up with new products and services for its customers.O2 should try and reduce the number of complaints of its satisfied the dissatisfied customers to ensure a stronger hold on its current market position.

\subsection{Recommendation for Vodafone}

The customers of Vodafone think that Vodafone is charging them quit high price than they should. To reduce this complaint, Vodafone should work on its pricing strategy. Vodafone has its call centers outside UK. According to some customers this is a disadvantage for the company. So the company should try to establish UK based call centers. Some customers of Vodafone have bad experience with the company due to the miscommunication between departments. Vodafone needs to improve inter department communication to clear this issue. As Vodafone is using the advanced technology for its business, the company should keep on introducing new technology to its customers. To hold a good position in the market and beat the competitors, Vodafone should apply some particular strategies to the business. Vodafone should try to satisfy the dissatisfiedcustomers of the company. As the company already has a good number of loyal customers, it should try to retain their loyalty.

\subsection{Recommendation for T-Mobile}

The customers of T-Mobile think that the company should stop charging the call to the MVNO numbers. T-Mobile can consider this option. The company is applying the low cost strategy which is giving it a good position in the market, but still it has two other competitors sitting on superior position in the market. TMobile should apply other strategies which will drive the company on a better position.

\subsection{Recommendation for Orange}

Though customers seem to be very happy about the services of Orange they think the small size tariff plan the company offers to its customers is not a very good tariff. Because people would like to have a handsome tariff plan along with a good hand set at moderate price. So Orange should work on this strategy and try restructuring it. In another tariff plan orange offers unlimited any time calls to UK landlines. But the customers are not considering this offer as a good one. They think Orange should try something like Orange to Orange unlimited any time calls. Orange is not following any particular strategy for its business which might drive the business to a difficult situation in future. Orange should try to go for a particular strategy to avoid unpleasant situation for the business in future. The company should also improve its abilities to beat the competitors and get hold of the leading position in the market. 


\section{References}

[1] Mark M. H., et.al. 2005. Determining Customer Satisfaction from Mobile Phones: A Neural Network Approach, Journal of Marketing Management, Vol. 21, p755-778 Available at: (http://proxy0.anglia.ac.uk:2059/science/article/pii/ S0167624598000158), Accessed on: (23 ${ }^{\text {rd }}$ June 2012)

[2] http://www.o2.co.uk/abouto2/history (Accessed on: $20^{\text {th }}$ June 2012)

[3] http://www.vodafone.co.uk/vodafone-uk/about-us/company-history/index.htm (Accessed on: $10^{\text {th }}$ April 2012)

[4] http://www.celtnet.org.uk/telecos/T-mobile.php(Accessed on: 10 ${ }^{\text {th }}$ April 2012)

[5] http://www1.orange.co.uk/about/history.html(Accessed on: $11^{\text {th }}$ July 2012)

[6] Mobile Market Research, Available at: (http://www.telecomsmarketresearch.com/ resources/UK_Mobile_Operator_Subscriber_Statistics.shtml), Accessed on: (1st July 2012)

[7] Passemard, D., \& Brian H. Kleiner, 2000. Competitive Advantage in Global Industries, Management Research News, Volume: 23, Issue: 7/8, p. 111-117.

[8] Passemard, D., \& Brian H. Kleiner, 2000. Competitive Advantage in Global Industries, Management Research News, Volume: 23, Issue: 7/8, p. 111-117.

[9] Porter, Michael, E., 2004. Competitive Advantage, New York: Free Press.

[10] Porter M. E., 'Competitive strategy: Techniques for analysing industries and competitors', Macmillan, New York (1980).

[11] Barney, J.B. (1991), Firm Resources and Sustained Competitive Advantage, Journal of Management, 17, pp. 99-120.

[12] Hall, R. (1992), The Strategic Analysis of Intangible Resources, Strategic Management Journal, Vol. 13 No. 2, pp. 135-44.

[13] Lieberman, M. and Montgomery, D. (1988), First mover Advantages, Strategic Management Journal, 9, pp. 41-58.

[14] Nonaka, I. (1991), “The knowledge-creating company", Harvard Business Review, NovemberDecember, pp. 2-9.

[15] Prahalad, C.K. and Hamel, G. (1990), "The core competence of corporations", Harvard Business Review, May-June, pp. 79-91.

[16] Teece, D.J., Pisano, G. and Shuen, A. (1997), "Dynamic capabilities and strategic management", Strategic Management Journal, Vol. 18, pp. 509-33.

[17] Ma, Hao, 1999. Creation and Pre-emption for Competitive Advantage, Management Decision, Volume: 37, Issue: 3, p. 259-266.

[18] Ma, Hao, 1999. Creation and Pre-emption for Competitive Advantage, Management Decision, Volume: 37, Issue: 3, p. 259-266.

[19] Ma, Hao, 1999. Creation and Pre-emption for Competitive Advantage, Management Decision, Volume: 37, Issue: 3, p. 259-266.

[20] Porter, Michael, E., 1998. The Competitive Advantage of Nations, London: Macmillan Press Ltd.

[21] Johnson, Michael D. and ClaesFornell (1991), "A Framework for Comparing Customer Satisfaction Across Individuals and Product Categories,” Journal of Economic Psychology, 12 (2), 267-86.

[22] Fornell, Claes (1992), "A National Customer Satisfaction Barometer; The Swedish Experience." Journal of Marketing, 55 (January). 1-21.

[23] Fornell, C., \&Wernerfelt, B. (1986). Defensive Marketing Strategy by Customer Complaint Management: A theoretical Analysis. Journal of Marketing Research, 24(4), 337-346.

[24] Bolton, Ruth N. and Katherine N. Lemon (1999), "A Dynamic Model of Customers' Usage of Services: Usage as an Antecedent and Consequence of Satisfaction," Journal of Marketing Research, 36 (May), 171-86.

[25] Porter, Michael, E., 1985. Competitive Advantage, New York: Macmillan Inc.

[26] Oliver, Richard L. (1999), "Whence Consumer Loyalty?” Journal of Marketing, 63 (Special Issue), 3344.

[27] Bolton, Ruth N. (1998), "A Dynamic Model of the Duration of the Customer's Relationship with a Continuous Service Provider: The Role of Satisfaction," Marketing Science, 17 (Winter), 45-65.

[28] Bolton, Ruth N. and Katherine N. Lemon (1999), “A Dynamic Model of Customers' Usage of Services: Usage as an Antecedent and Consequence of Satisfaction," Journal of Marketing Research, 36 (May), 171-86.

[29] Porter, Michael, E., 1985. Competitive Advantage, New York: Macmillan Inc.

[30] Hunt, H. Keith (1977). "CS/D—Overview and Future Research Directions." in Conceptualization and Measurement of Customer Satisfaction and Dissatisfaction, H. Keith Hunt, ed. Cambridge. MA: Marketing Science Institute, 455-88. 
[31] Oliver, R.L. (1980) "A Cognitive Model of the Antecedents and Consequences of Satisfaction Decisions", Journal of Marketing Research, Vol. 17, (November), pp.460-469.

[32] Fornell, Claes (1992), "A National Customer Satisfaction Barometer; The Swedish Experience." Journal of Marketing, 55 (January). 1-21.

[33] Johnson, Michael D. and ClaesFornell (1991), “A Framework for Comparing Customer Satisfaction Across Individuals and Product Categories,” Journal of Economic Psychology, 12 (2), 267-86.

[34] Mobile Market Trends: UK Data to engage with consumers, 2010-2012, Available at: (www.mobilesquared.co.uk/pdfs/mobile_market_trends_uk.pdf), Accessed on: (1st July 2012).

[35] Mobile Market Research, Available at: (http://www.telecomsmarketresearch.com/resources/UK_Mobile_Operator_ Subscriber_Statistics.shtml), Accessed on: (1st July 2012)

[36] Passemard, D., \& Brian H. Kleiner, 2000. Competitive Advantage in Global Industries, Management Research News, Volume: 23, Issue: 7/8, p. 111-117.

[37] Porter, Michael, E., 1998. The Competitive Advantage of Nations, London: Macmillan Press Ltd.

[38] Porter, Michael, E., 2004. Competitive Advantage, New York: Free Press.

[39] Passemard, D., \& Brian H. Kleiner, 2000. Competitive Advantage in Global Industries, Management Research News, Volume: 23, Issue: 7/8, p. 111-117.

[40] Stewart, T.A. (1997), Intellectual Capital: The New Wealth of Organizations, Doubleday/Currency, New York, NY.

[41] Fornell C, Johnson MD, Anderson EW, Cha J, Bryant BE (1996). The American customer satisfaction index: nature, purpose, and findings. J. Mark., 60:7-18. 